\title{
Correction to: Using a Nonconcurrent Multiple-Baseline Across-Participants Design to Examine the Effects of Individualized ACT at School
}

\author{
Alyssa N. Wilson ${ }^{1} \cdot$ Emily Dzugan ${ }^{2} \cdot$ Victoria D. Hutchinson ${ }^{2}$ \\ Published online: 8 July 2021 \\ (C) Association for Behavior Analysis International 2021
}

Correction to: Behavior Analysis in Practice. https://doi.org/10.1007/s40617-021-00558-8

This article was updated to use the correct version of Fig. 1.

Publisher's Note Springer Nature remains neutral with regard to jurisdictional claims in published maps and institutional affiliations.

The online version of the original article can be found at https://doi.org/ 10.1007/s40617-021-00558-8

Alyssa N. Wilson awilson8@thechicagoschool.edu

1 The Chicago School of Professional Psychology, Los Angeles Campus, 707 Wilshire Blvd, Los Angeles, CA 90017, USA

2 School of Social Work, Saint Louis University, St. Louis, MO, USA 